\title{
Negative and affirmative sentences increase activation in different areas in the brain
}

\author{
Ken Ramshøj Christensen ${ }^{a, b, *}$ \\ a Department of English, Institute for Language, Literature, and Culture, University of Aarhus, Aarhus, Denmark \\ ${ }^{\mathrm{b}}$ Center for Functionally Integrative Neuroscience, Aarhus University Hospital, Aarhus, Denmark
}

Received 29 January 2008; received in revised form 29 April 2008; accepted 1 May 2008

\begin{abstract}
Though negation is unique and central to human language, it has so far received little attention in cognitive neuroscience. The goal of the present study was to investigate the contrast between affirmative and negative sentences using fMRI, focusing on two central aspects, namely, (1) a semantic difference: affirmation is upward entailing, whereas negation is downward entailing; (2) a syntactic difference: negation involves more syntactic structure than affirmation. The behavioural data showed that negation significantly increased response times (but not the level of performance), even when negation was only in the preceding context to the response condition. The imaging results showed increased activation in the left premotor cortex from negation, compatible with rule-governed memory processing, and increased activation in the right supramarginal gyrus from affirmation, compatible with semantic processing. Finally, affirmation showed "default mode" activation in the cingulate cortex.
\end{abstract}

(c) 2008 Elsevier Ltd. All rights reserved.

Keywords: Negation; Polarity; Syntax; fMRI; Premotor; BA 6; Supramarginal gyrus; BA 40; Default mode; Cingulate gyrus

\section{Introduction}

Language shares many of its design features with communication systems of other species (Hockett, 1966) whereas other features are unique to human language. One of the more striking

\footnotetext{
* Department of English, Institute for Language, Literature, and Culture, University of Aarhus, Jens Chr. Skous Vej 5, DK-8000 Aarhus C, Denmark. Tel.: +45 89426521; fax: +45 89426540.

E-mail address: engkrc@hum.au.dk
} 
unique features is negation: "All human systems of communication contain a representation of negation. No animal communication system includes negative utterances, and consequently none possesses a means for assigning truth value, for lying, for irony, or for coping with false or contradictory statements [...]" (Horn, 2001: xiii). Even though negation is central to human language and cognition in general, it has so far received little attention within cognitive neuroscience. To our knowledge, the only examples of neuroimaging studies on negation in the literature are Carpenter, Just, Keller, Eddy, and Thulborn (1999), Christensen (2008), Christensen, Roepstorff, Saddy, Stødkilde-Jørgensen, and Vikner (submitted for publication), Hasegawa, Carpenter, and Just (2002), and Tettamanti et al. (2006). Two of these (Christensen, 2008; Christensen et al., submitted for publication) did not involve a contrast between affirmative and negative sentences, and therefore they will not be discussed below.

The goal of the present study was to investigate the neural correlates of the contrasts between affirmative and negative sentences using functional magnetic resonance imaging (fMRI). The most obvious difference is that they have opposite truth values (i.e., since The Earth is flat is false, then The Earth is not flat is necessarily true). However, the present study focused on two other linguistic core differences, namely, (i) a semantic difference in the direction of entailment and (ii) a difference in amount of syntactic structure. An affirmative sentence is upwards entailing which means that if a proposition about an element, say, an apple, is true, the same proposition will also be true about the superset of the element, in the case of apples, the superset is fruit, see example (1) and Fig. 1. Negation, on the other hand, is downward entailing which means that if a negated proposition about, e.g., apples is true, the same will hold for the subsets of apples, say, Granny Smith and Gala, see example (2) and Fig. 1.

\section{(1)}

I would like to buy some apples
$\rightarrow$ I would like to buy some fruit

$* \rightarrow$ I would like to buy some Granny Smith

(2) I would not like to buy some apples

$* \rightarrow$ I would not like to buy some fruit

$\rightarrow$ I would not like to buy some Granny Smith

\section{(affirmative) \\ (upward) \\ (downward)}

(negative)

(upward)

(downward)

Arguable then, since the entailment in affirmatives is upwards and goes from subset to superset, from specific to general, whereas with negatives the direction is the inverse, affirmatives engage semantic networks at a higher, more abstract, hierarchical level; this is not the case with negation. In other words, then, an affirmative sentence involves more general semantic 'structure' than a negative sentence.
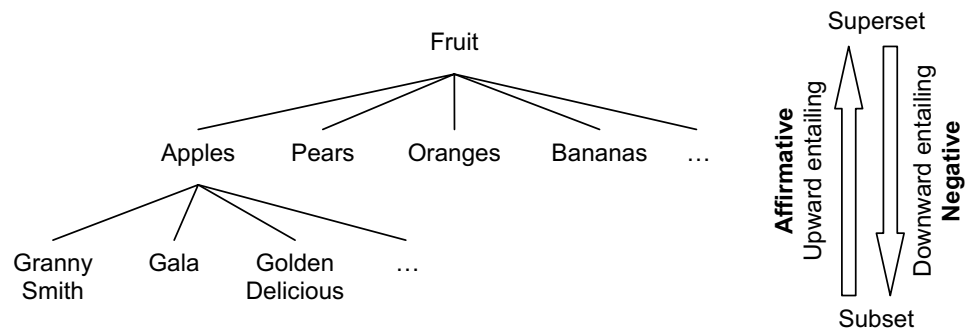

Fig. 1. Semantic hierarchy and entailment. 
On the syntactic side, however, the relationship is reversed. Negative sentences have more syntactic structure than affirmatives since there is a part of the syntactic structure dedicated to negation (Christensen, 2005; Haegeman, 1995; Pollock, 1989). The piece of syntactic structure that is unique to negative clauses is labelled NegP, short for Negation Phrase, see Fig. 2. $\mathrm{NegP}$ is projected by the negative head $\mathrm{Neg}^{\circ}$ which in English may be realised as the suffix - $n^{\prime} t$ which must be attached to an auxiliary verb, or it may be abstract, phonetically silent, in case its specifier is realised as, e.g., not or never. In French, for example, both $\mathrm{Neg}^{\circ}$ and its specifier may have a phonetic realisation, namely, as the prefix $n(e)$ - and pas, respectively. In Danish, the negative operator ikke 'not' occupies the same position as the English not, namely, specNegP, see Fig. 2.

Linguistic evidence in support of a syntactic difference between affirmative and negative comes, for example, from 'negative islands' (or 'inner islands', Ross, 1984; Vikner, 1995) and the so-called 'what-for' split found in many Germanic languages (but not English) (Vikner, 1995). For example, in colloquial Danish there are two semantically (more or less) equivalent ways of forming a affirmative wh-question, namely, either by fronting the entire $w h$-phrase or by fronting the wh-word alone, corresponding literally to What for students did you invite? and What did you invite for students?, respectively. With negation, however, only the former is licensed, whereas the what-for split is blocked. Leaving a host of details aside, this at least suggests a structural difference, since if affirmatives were to involve an abstract (phonetically silent, but syntactically and semantically real) operator in the same position that negation

a

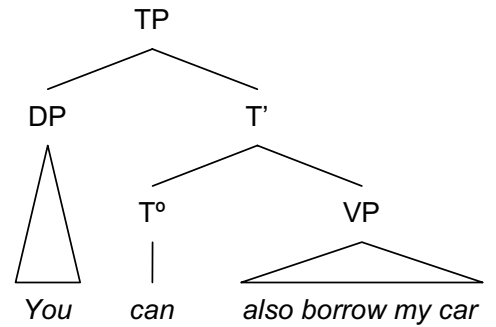

b

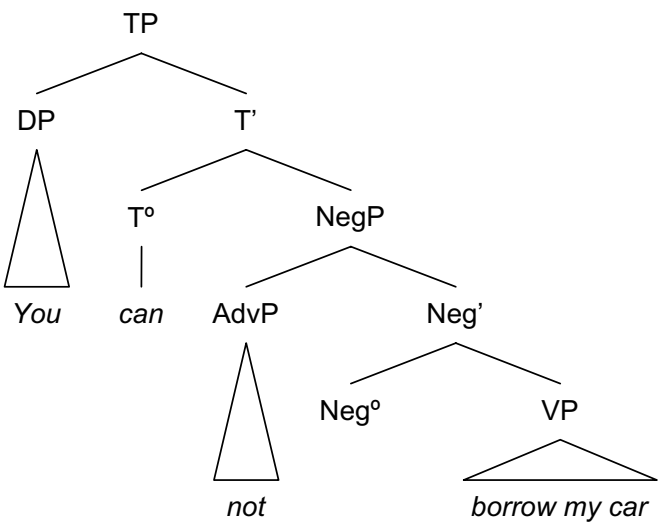

Fig. 2. Simplified sentence structures with (a) positive and (b) negative polarity. $\mathrm{TP}=$ Tense $\mathrm{Phrase}, \mathrm{DP}=$ Determiner Phrase, $\mathrm{NegP}=$ Negation Phrase, AdvP $=$ Adverb Phrase, $\mathrm{VP}=$ Verb Phrase. 
occupies in negative clauses, it would remain a mystery why the what-for split is possible in affirmative but not in negative clauses.

Further support for a syntactic difference comes from studies on event-related brain potentials (ERP) and negative and positive polarity items (NPI and PPI, respectively). In short, NPIs, such as ever, are licensed under negation, cf. No/*Some man was ever happy, whereas PPIs, such as certainly, are licensed outside the scope of negation, cf. Some/*No man was certainly happy. Saddy, Drenhaus, and Frisch (2004) found that unlicensed NPIs and PPIs both triggered a so-called N400 (a negative-going effect app. $400 \mathrm{~ms}$ post stimulus), usually taken to reflect cost of semantic integration. In addition, unlicensed PPIs, but not NPIs, also induced a P600 (positive effect $600 \mathrm{~ms}$ post stimulus), usually assumed to reflect structural reanalysis. Saddy, Drenhaus, et al. (2004) argue that the cause for this difference lies in the nature of the constructions. In their study, unlicensed NPIs were not in the scope of negation and interpretation failed because something was missing, namely, NegP. No structural repair is attempted and, hence, no P600. With unlicensed PPIs, structural reanalysis was attempted (and failed) in order to get the PPI outside the scope of negation, hence, the P600.

In psycholinguistics, it has also been argued that negation clauses introduce two propositions, namely, the proposition itself plus its cancellation, the negated version (Jordan, 1998). Furthermore, it has been argued that negation is in fact, an affirmative with a negative operator added to it, and that negation is initially interpreted as affirmation (Carpenter \& Just, 1975; Chase \& Clark, 1972). This is also the result of a recent psycholinguistic priming experiment by Hasson and Glucksberg (2006). As primes they used sentences such as My lawyer was a shark (affirmative) and My lawyer wasn't a shark (negative), and as target single adjectives, such as, Vicious (Aff-related: related to the affirmative prime) and Gentle (Neg-related: related to the negative prime). Furthermore, Hasson and Glucksberg (2006) varied the interval between the prime and the target (stimulus onset asynchrony, SOA). The results showed that with SOAs up to $1000 \mathrm{~ms}$, both affirmatives and negatives prime Aff-related targets. With SOAs above $1000 \mathrm{~ms}$, affirmatives primed Aff-related targets, and negatives primed Neg-related targets. In short, the initial interpretation of negation is its cancellation, the affirmative. This also offers an account for why negation requires more response time and induces more errors and, hence, why negation is more difficult than its affirmative counterpart (Carpenter \& Just, 1975; Carpenter et al., 1999; Chase \& Clark, 1972; Hasegawa et al., 2002).

It could be argued that different types of negative sentences are represented in the mind and processed differently, for example depending on whether they contain bipolar predicates (such as above whose negation, not above, is not the same as below) or contradictory predicates (such as, open, guilty, and active where there are a positive version of their negation, not open/guilty/ active, namely, closed, innocent, and passive) (e.g., Mayo, Schul, \& Burnstein, 2004). However, Kaup, Lüdtke, and Zwaan $(2006,2007)$ present data to the contrary and argue that comprehending a negative sentence, say, The door is not open, is a two-step process: first, the negated state of affairs (the positive version The door is open) is represented and subsequently attention is shifted towards the representation of the actual state of affairs (i.e., The door is closed). In the comprehension of a positive sentence, on the other hand, the actual state of affairs is immediately represented.

As mentioned, negation has not yet received much attention in neuroimaging. However, Carpenter et al. (1999) present data from an fMRI study on negation in which the experimental task was a sentence-to-picture matching task. For example, the subjects were presented with a sentence with or with out negation such as It is (not) true that the star is above the plus and was subsequently shown a picture of a plus ' + ' above an asterisk ' $*$ ' and had to answer whether it 
was true or false. As expected, Carpenter et al. (1999) found that subjects responded slower to negatives than to affirmatives. Furthermore, they report that negatives resulted in significantly more activation than affirmatives. However, they applied a very narrowly defined region of interest, namely seven coronal slices covering posterior temporal cortex (BA 22, 37), and superior parietal (BA 5, 7) and inferior parietal (supramarginal gyrus, henceforth, SMG [BA 40] and angular gyrus [BA 39]). Within this region of interest, negation induced increased activation in the parietal region bilaterally and in left posterior temporal cortex. No affirmative effect was reported.

Hasegawa et al. (2002) used a probe-to-target matching task in their fMRI study. The subjects were Japanese bilingual speakers with English as their second language. In the task, the subjects were first exposed to biclausal affirmative or negative examples, such as The worker read a magazine and showed some pictures to the brother (target) and subsequently to monoclausal affirmative or negative examples, e.g., The worker read a magazine (probe). They were then asked to judge whether or not the probe was true or false. The stimulus material included both Japanese and English material. The behavioural results showed that negatives took longer time to process and induced more errors than affirmatives in both Japanese and English. The imaging results, on the other hand, showed effects only for negatives (relative to affirmatives), only in the subjects second language, i.e., English, and the activations were only significant in the left hemisphere: Posterior temporal cortex (BA 21, 22, 37), the SMG gyrus (BA 40), and the precentral cortex (including parts of the frontal eye fields and BA 6). It is, however, unknown whether the imaging data were recorded during the targets or the probes.

The study reported by Tettamanti et al. (2006), contrasted affirmative and negative sentences such as I do kick a ball and I do not kick a ball. Their results showed that the NEG $>$ AFF contrast, i.e., the effect of negatives relative to affirmatives, increased activation in the left inferior frontal gyrus, an effect not reported in the previous two studies (Carpenter et al., 1999; Hasegawa et al., 2002). Even more puzzling, the inverse contrast, AFF > NEG (i.e., the effect of affirmatives relative to negatives), revealed bilateral activation in dorsal premotor and in and around the posterior intraparietal sulcus - more or less the two regions found to be activated by negation in the other studies.

Based on the data and the findings in literature discussed so far, the following three cortical regions involved would be predicted to be involved in the contrast between negative and affirmative sentences: left premotor cortex (BA 6), bilateral parietal cortex (the SMG, BA 40), possibly extending into the posterior temporal region, and the left inferior frontal gyrus. More specifically:

(3) Left premotor (BA 6)

Negative $>$ affirmative

Hasegawa et al. (2002).

Affirmative $>$ negative

Tettamanti et al. (2006).

(4) Inferior parietal (SMG BA 40)

Negative $>$ affirmative

Carpenter et al. (1999), bilateral effect;

Hasegawa et al. (2002), left only (possibly

including posterior temporal cortex).

Affirmative $>$ negative

Tettamanti et al. (2006), bilateral effect.

Apart form its role in motor programming and execution (Joseph, 1996), BA 6 has also been found to engaged in a number of structure-dependant non-motor mental tasks, including working memory, linguistic, spatial, and numerical tasks (Ben-Shachar, Hendler, Kahn, Ben-Bashat, \& Grodzinsky, 2003; Ben-Shachar, Palti, \& Grodzinsky, 2004; Bor, Cumming, Scott, \& Owen, 
2004; Bor \& Owen, 2007; Bornkessel, Zysset, Friederici, von Cramon, \& Schlesewsky, 2005; Christensen, 2008; Dogil et al., 2002; Hanakawa et al., 2002; Röder, Stock, Neville, Bien, \& Rösler, 2002; Smith \& Jonides, 1999). It appears, then, that at least part of the function of BA 6 has to do with structure processing (as is also the case in motor programming). The inferior parietal cortex is involved in multimodal association, categorization, and labelling and, hence, in high-level semantic representations (Fuster, 2003; Joseph, 1996; Jung-Beeman, 2005; Mesulam, 1998, 2002). As argued above, negative and affirmative sentences involve increased syntactic and semantic hierarchical structure, respectively, and these two factors are easily compatible with the cognitive functions of premotor (BA 6) and inferior parietal cortex. (I return to the lack of consensus between the studies in (3) and (4) in the discussion.) Moreover, since the left inferior frontal gyrus has been found to be recruited in tasks involving computation of various types of syntactic complexity (Christensen, 2008; Grodzinsky, 2000; Moro et al., 2001; Pinker, 1999; Stromswold, Caplan, Alpert, \& Rauch, 1996), this area was also predicted to show an effect of the additional structure of negation, as was indeed also the case in Tettamanti et al. (2006).

\section{Methods}

\subsection{Subjects}

Nineteen native speakers of Danish ( 7 female, 12 male), aged between 22 and 37 years (average $=27.5$ ), participated in the study. They were all right-handed with no medical history of mental deficits or neurological trauma. Informed written consent was obtained from all participants prior to the experiment.

\subsection{Materials}

The experimental task was a probe-to-target matching task similar to the one used by Hasegawa et al. (2002). Biclausal affirmative and negative target sentences, see (5), were presented visually for $5 \mathrm{~s}$, followed by an arrow projected in the center of the screen, which the subjects were instructed to interpret as something like "from this is follows that", and which remained onscreen for $1 \mathrm{~s}$. Then an affirmative or a negative monoclausal probe, see (6), was presented for $3 \mathrm{~s}$, and the task was to answer yes or no, within the $3 \mathrm{~s}$, by pressing a left or right button with the index or middle finger, respectively. The 1-s pause between target and probe should ensure that negative sentences are indeed mentally represented as negatives (Hasson \& Glucksberg, 2006; Kaup et al., 2006, 2007). After the probe, a plus was shown centered in the screen for $2 \mathrm{~s}$, before the next target appeared. The sequence is illustrated in Fig. 3.

(5) Targets: $\quad$ AFF: De sejeste mænd kender og bruger også sæbe

The toughest men know and use also soap

"The toughest men know and also use soap."

NEG: De sejeste mænd kender men bruger ikke sæbe

The toughest men know but use not soap

"The toughest men know but don't use soap." 


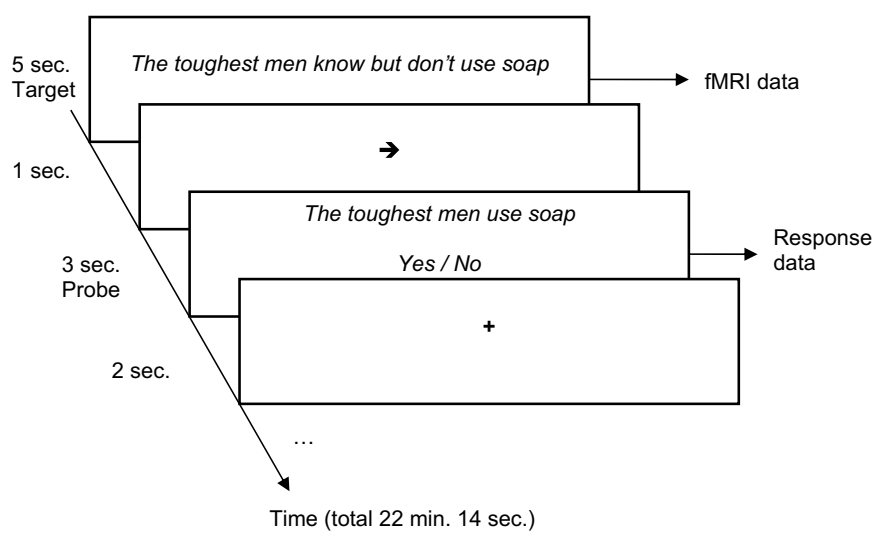

Fig. 3. Experimental design.

(6) Probes: AFF: De sejeste mænd kender sæbe

The toughest men know soap

"The toughest men know soap."

NEG: De sejeste mænd kender ikke sæbe

The toughest men know not soap

"The toughest men don't know."

The entire stimulus set consisted of 28 target-probe pairs with 14 negative and 14 positive targets and probes, such that there were seven of each of the four combinations of affirmative and negative (Aff-Aff, Aff-Neg, Neg-Aff, Neg-Neg). The full set of sentences is listed in the Appendix. The pairs were presented in pseudo-random order and separated by three types of fillers (excluded from the analysis): (i) garden-path versions of the relevant stimulus, e.g., The toughest men know use/don't use soap too (locally ambiguous between [the toughest men] know... and the toughest [men know]...), (ii) comparative constructions, such as, More people have been to Paris than to Oslo, and (iii) non-sensical comparative constructions, e.g., More people have been to Paris than I have. (The fillers will not be discussed here.)

Before scanning, the subjects were trained on the task with different stimuli. To avoid motor artifacts in the imaging data, the fMRI analysis was applied to images acquired during the targets, not the probes.

\subsection{Procedure}

Functional images were acquired on a General Electrics 3 Tesla MR system with a standard head coil. The volumes consisted of 39 axial slices (thickness $=3.5 \mathrm{~mm}$, spacing $=0$ ) covering the entire cerebrum and cerebellum. FOV $=24 \times 24$ voxels, matrix $=64 \times 64$ voxels (in-plane resolution $=3.75 \times 3.75 \mathrm{~mm}$ ). Flip angle $=90, \mathrm{TE}=30, \mathrm{TR}=3 \mathrm{~s}$.

\subsection{Data analysis}

The data were analysed with SPM5 (Wellcome Department of Imaging Neuroscience, University College London). The imaging data were realigned to correct for movement, normalised to the Talairach Space (Talairach \& Tournoux, 1988) (reslicing the voxels to $2 \times 2 \times 2 \mathrm{~mm}$ ), 
smoothed with a $10 \mathrm{~mm}$ Gaussian kernel FWHM to correct for random variation in signal intensity, and finally submitted to a random-effect analysis. The localisation and extent of the activation clusters were analysed using the MNI Space Utility (The PET Lab, Institute of the Human Brain, St. Petersburg, Russia).

\section{Results}

\subsection{Behavioural results}

Fig. 4 shows the response times (RT) averaged across the four types of target-probe pairs. A two-way repeated measures ANOVA with target and probe polarity as factors showed that there was no target-by-probe interaction $(p=0.662, F=0.252)$ and, hence, no significant difference between the types of four target-probe pairs in Fig. 4. The main probe effect was marginally significant ( $p=0.053, F=3.840$ ). However, a direction in the results was predicted, namely, negative $>$ affirmative, and indeed the difference was significant on a one-tailed $t$-test ( $p=0.027$ ), see Fig. 5, bottom left. That is, subjects responded significantly slower to negative probes (mean $\mathrm{RT}=1939.5 \mathrm{~ms}, \mathrm{SD}=267.6$ ) than to affirmative probes (mean $\mathrm{RT}=1845.6 \mathrm{~s}$, $\mathrm{SD}=299.3)$, regardless of whether the target was affirmative or negative $(\mathrm{Neg}-\mathrm{Neg}$ and Aff-Neg $>$ Neg-Aff and Aff-Aff). Likewise, the main target polarity effect was not significant on the two-way ANOVA ( $p=0.110, F=2.841)$, but a one-tailed $t$-test showed the negative $>$ affirmative difference to be marginally significant $(p=0.055)$, cf. Fig. 5, upper left. This means that negative targets had a marginally significant influence on the response time on the probes (Neg-Neg and Neg-Aff $>$ Aff-Neg and Aff-Aff).

Fig. 6 shows the average levels of correct performance across target-probe pairs. The percentages were transformed with an arcsine function $(f(x)=2 \times \operatorname{ASIN}(\sqrt{ } x))$ and submitted to a two-way repeated measures ANOVA which showed no significant main effects (target: $p=0.533$, probe: $p=0.998)$ and no significant interaction $(p=0.201)$. In short, there was no difference in correct performance between negative and affirmative.

\subsection{Imaging results}

The result revealed four significant clusters, see Table 1 for details: one for the negative $>$ affirmative subtraction, cluster (i), in the left BA 6 (and parts of BA 8, 9); three clusters

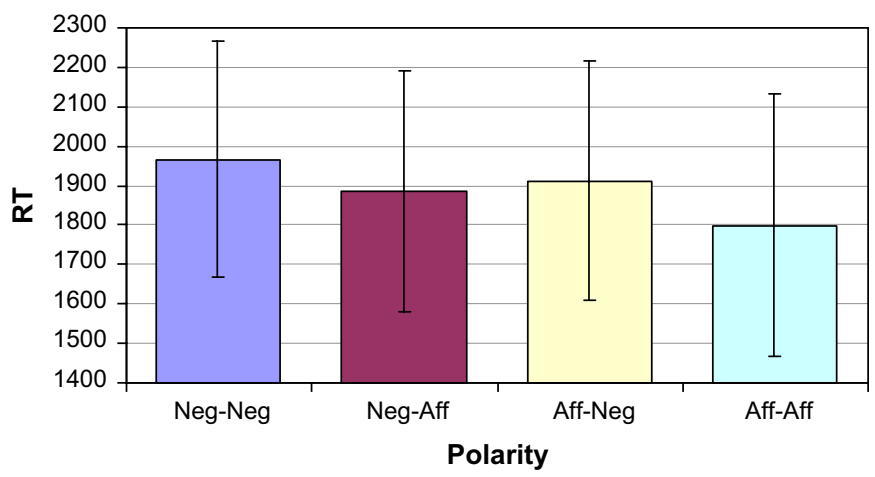

Fig. 4. Response times across target-probe pairs. Neg-Neg is short for 'Negative target and Negative probe', Aff-Neg for 'Affirmative target, Negative probe', and so forth. 

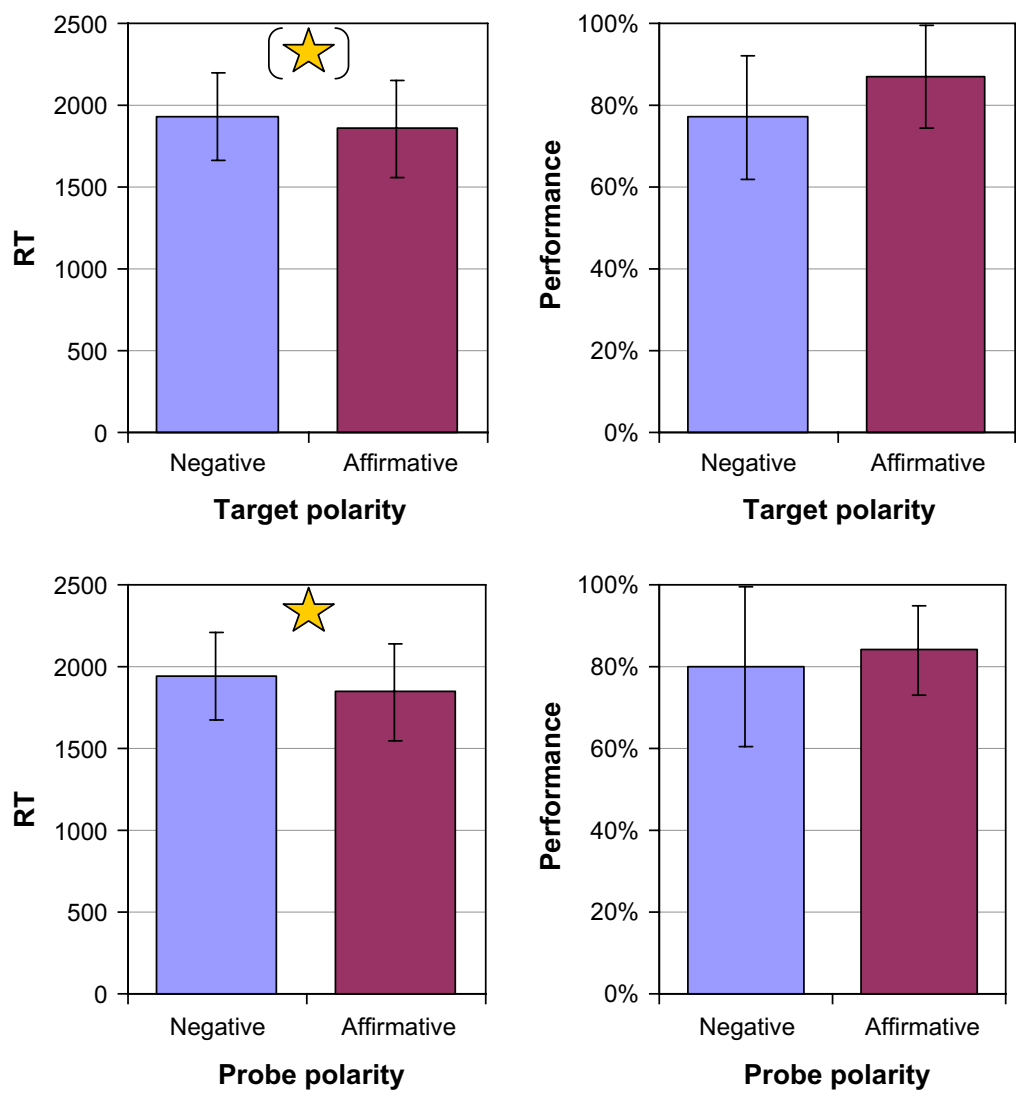

Fig. 5. Main effects. Response times (left column) and performance levels (right column) on target polarity across probe polarity (top row) and on probe polarity across target polarity (bottom row).

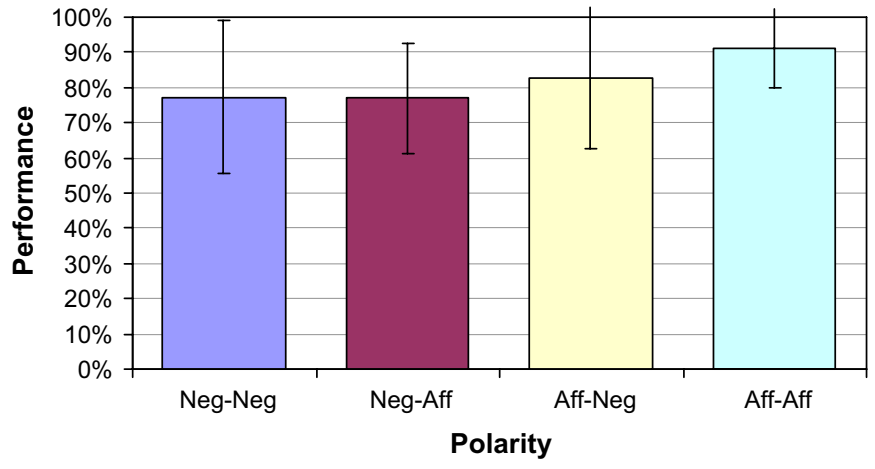

Fig. 6. Levels of correct performance across target-probe pairs. Neg-Neg $=$ 'Negative target and Negative probe', Aff-Neg = 'Affirmative target, Negative probe', etc. 
Table 1

Imaging results

\begin{tabular}{|c|c|c|c|c|c|c|c|c|}
\hline \multirow[t]{2}{*}{ Subtraction } & \multirow[t]{2}{*}{ Cluster \# } & \multirow[t]{2}{*}{ Cluster $p$ (corr.) } & \multirow[t]{2}{*}{ Cluster size (voxels) } & \multirow[t]{2}{*}{ S.V.C. $p$ (FDR) } & \multirow{2}{*}{$\frac{\text { Voxels }}{T \text {-value }}$} & \multicolumn{3}{|c|}{ Local maxima } \\
\hline & & & & & & $x$ & $y$ & $z$ \\
\hline \multirow[t]{3}{*}{$\mathrm{Neg}>$ Aff } & \multirow[t]{3}{*}{ (i) } & \multirow[t]{3}{*}{0.001} & \multirow[t]{3}{*}{476} & \multirow[t]{3}{*}{$\leq 0.004$} & 5.62 & -36 & -6 & 46 \\
\hline & & & & & 4.97 & -44 & 2 & 42 \\
\hline & & & & & 4.84 & -52 & 6 & 44 \\
\hline \multirow[t]{9}{*}{ Aff $>$ Neg } & \multirow[t]{3}{*}{ (ii) } & \multirow[t]{3}{*}{0.000} & \multirow[t]{3}{*}{675} & \multirow[t]{3}{*}{$\leq 0.004$} & 5.36 & 60 & -46 & 32 \\
\hline & & & & & 4.90 & 62 & -38 & 38 \\
\hline & & & & & 4.80 & 56 & -44 & 44 \\
\hline & \multirow[t]{3}{*}{ (iii) } & \multirow[t]{3}{*}{0.000} & \multirow[t]{3}{*}{769} & \multirow[t]{3}{*}{$\leq 0.003$} & 5.69 & 4 & 38 & 22 \\
\hline & & & & & 4.82 & 0 & 46 & 12 \\
\hline & & & & & 4.80 & 6 & 12 & 28 \\
\hline & \multirow[t]{3}{*}{ (iv) } & \multirow[t]{3}{*}{0.002} & \multirow[t]{3}{*}{442} & \multirow[t]{3}{*}{$\leq 0.022$} & 4.91 & 14 & -50 & 42 \\
\hline & & & & & 4.49 & 0 & -16 & 40 \\
\hline & & & & & 4.47 & 0 & -30 & 46 \\
\hline
\end{tabular}

Significance thresholds: voxels $p<0.001$ (uncorrected for multiple comparisons), clusters $p<0.05$ (corrected).

for the affirmative $>$ negative contrast, namely, cluster (ii) right BA 40, (iii) bilateral anterior cingulate (as well as some bilateral medial frontal cortex), and (iv) bilateral posterior cingulate (some right precuneus, and bilateral paracentral lobule).

Cortical renderings of clusters (i) and (ii) are shown in Fig. 7 and (iii) and (iv) are shown in Fig. 8.

\section{Discussion}

The behavioural data are compatible with the results in the literature and clearly suggest that negatives are cognitively different from affirmatives, although in the present study negation had an influence on response time alone and not on the level of performance. More
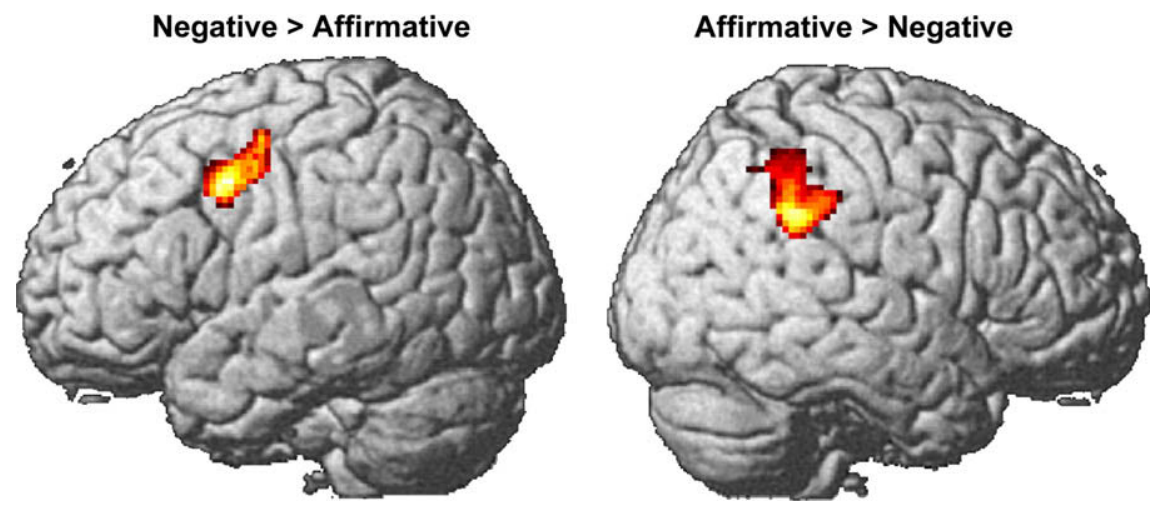

Fig. 7. Surface renderings of imaging contrasts. Left image shows the activation in left-hemisphere BA 6 resulting from of negative $>$ affirmative (see cluster (i) in Table 1); right image shows the right-hemisphere effect in SMG (BA 40) resulting from the affirmative $>$ negative (see cluster (ii) in Table 1). 


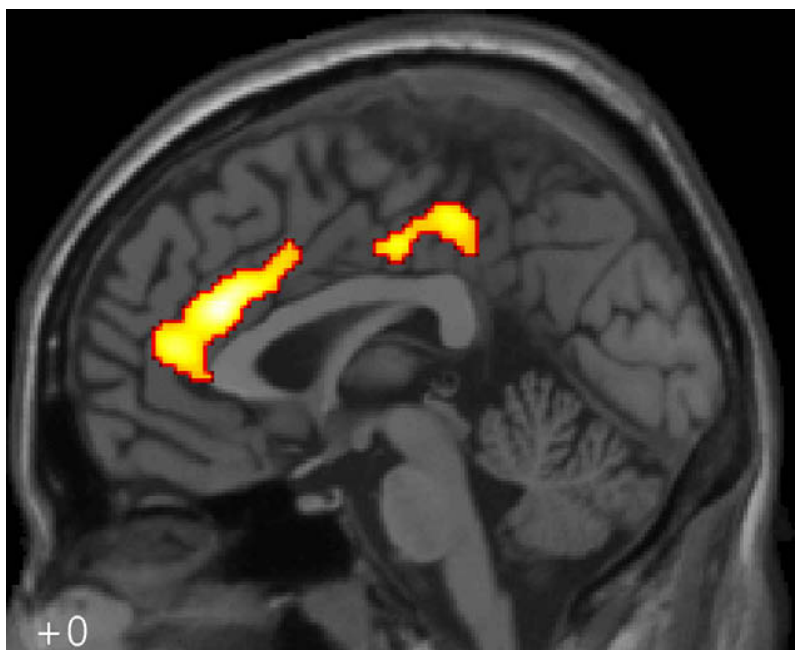

Fig. 8. Affirmative $>$ negative contrast. Midline sagittal slice showing the anterior and posterior cingulate activations (clusters (iii) and (iv) in Table 1, respectively).

specifically, negation requires more processing time regardless of whether negation was in the probe to which the subjects actually responded, or in the target immediately preceding the probe.

In Section 1 above, the prediction was made that the regions engaged in affirmative and negative sentences would include left BA 6, bilateral or left lateralised BA 40, and the LIFG. First of all, it is noteworthy that there was no activation change in LIFG, neither for negative $>$ affirmative nor for affirmative $>$ negative. Secondly, and curiously, the negative (>affirmative) and the affirmative (>negative) are in separate hemispheres, negative in the left, affirmative in the right. Thirdly, both BA 6 and BA 40 were found to be involved.

Negative showed increased activation in the left premotor cortex, BA 6. This corroborates the result in Hasegawa et al. (2002), but contrasts with Tettamanti et al. (2006) who reported the left BA 6 to be activated by affirmative (or, as they argue, negative showed decreased activation in BA 6 relative to affirmative).

It is interesting that BA 6 is engaged since neither affirmative nor negative involved any motor response. BA 6 is otherwise highly involved in the programming (i.e., intention and guidance) of movement (Joseph, 1996: 399), especially the trajectory of movement (Fuster, 2003: 77). However, Hanakawa et al. (2002), also found this area to be activated in non-motor tasks which involved rule-based, non-motor "mental-operation tasks", namely, numerical (silently adding number between 1 and 9), verbal (going through weekdays, say, Wednesday plus $2=$ Friday), and spatial tasks (mentally moving a dot on the screen in a specified direction). Crucially, none of the tasks involved motor activity, only cognitive, rule-based manipulation of representations in short-term memory. Note that there is no conflict between these different findings, i.e., motor programming and non-motor, rule-based computation, since motor programming is also rule-governed computation.

The activation in BA 6 and the involvement in rule-base, mental-operation tasks are compatible with the suggested trigger for activation, namely, syntactic structure. As illustrated in Fig. 2, negative clauses involve additional structure, NegP, compared to affirmative clauses. 
This structure is required to house the negative operator (e.g., not in English). The lack of activation in LIFG is interesting, since it has often been argued to be crucial to in tasks involving increased syntactic complexity. However, there is really only a conflict if one assumes that syntax involves only LIFG. In fact, it has been argued that syntactic computation involves a widely distributed, bilateral network, including inferior frontal, posterior temporal, dorsal prefrontal, anterior cingulate, and cerebellar regions (Christensen, 2008). The present study adds BA 6 to this network. Which part or parts of the network showing increased activation, depend on the specific minimal contrast in syntactic processing.

Affirmative (>negative) showed increased activation in the right SMG (BA 40). This result is in contrast to those reported by Carpenter et al. (1999) and Hasegawa et al. (2002) who found negative to engage the SMG (bilaterally and left lateralised, respectively). Tettamanti et al. (2006), on the other hand, also reported affirmative to increase parietal activation (though their effect was bilateral).

The SMG is involved in many cognitive tasks, including recognition of abstract spatial relations (Damasio et al., 2001) (as part of the inferior parietal cortex), representing movements in allocentric space (Farrer \& Frith, 2002), action execution, simulation, and observation (Grézes \& Decety, 2001), and in semantic retrieval of enacted action phrases, that is, phrases that are learnt by acting them out rather than by mere reading (Russ, Mack, Grama, Lanfermann, \& Knopf, 2003). The SMG is part of the temporo-occipito-parietal junction, a multimodal association convergence region, involved in lexical retrieval (Fuster, 2003) (The mental lexicon itself is distributed over much larger areas, if not the whole brain). This role in lexical retrieval or semantic look-up is also evident in lesion studies. A lesion in BA 40 may cause conduction aphasia which is characterized by word substitutions, naming problems, and a lack of ability to give a verbatim repetition of spoken words.

In short the SMG is involved in lexical retrieval by means of reactivation of high level, hierarchical, multimodal representations. The activation found in SMG in the affirmative conditions is compatible with such a functional role. The proposed trigger for the activation was semantic, more specifically, upward entailment (that is, entailment for subset to superset).

The curious fact that affirmative engages an area on the right hemisphere, whereas negative shows an effect on the left is compatible with the fact that linguistic impairments that affect the systems for structure building (morphology and syntax) tend to correlate with left-hemisphere lesions (usually with damage to Broca's area and its vicinity), and pragmatic deficits (including problems with making inferences) correlate with right-hemisphere lesions. (Incidentally, it also fits the popular model according to which the left hemisphere is specialised for analytic computation, the right for synthetic computation.)

As is clear from (3) and (4) above, the results in the literature, including the present study, are diverse and contradictory. Though the same areas are reported to be involved, and at least that is something, there is variation in the involvement of these areas and whether this effect is induced by negatives or affirmatives. First of all, there are only four experiments and, secondly, they are not replications of the same design; only the present study and Hasegawa et al. (2002) used the same type of probe-to-target matching task, whereas Carpenter et al. (1999) used a sentence-to-picture matching task. Tettamanti et al. (2006) used passive listening, i.e., no real experimental task, and given that there are no behavioural data it cannot be ascertained whether the subjects actually paid attention and processed or mentally represented in particular the negative sentences as predicted. Thirdly, there is a problem with the low number of participants in the other studies: Carpenter et al. (1999) had 8 participants, 
Hasegawa et al. (2002) 10 participants, and Tettamanti et al. (2006) 8. With so few participants, perhaps the results do not generalise to the population. Finally, Carpenter et al. (1999) used a very narrowly defined ROI which only included seven coronal slices of parietal and posterior temporal cortex, it is unknown whether any effect would have been found in BA 6 or elsewhere.

As argued in Section 1 above, affirmative (that is, positive polarity) is the default polarity: a negative is an affirmative with a negative operator added to it; negatives are initially interpreted as affirmatives. The present behavioural results also lend support to a default role of affirmative. From a structural point of view, a negative sentence has more syntactic structure (namely, NegP) and, hence, when compared to a corresponding affirmative sentence, something is added to the structure in order to get the negative (and this extra structure gave rise to the BA 6 effect). It has been argued that certain networks of areas in the brain have a default level of activation, an intrinsic or self-referential "default mode" (e.g., Franson, 2006; Raichle et al., 2001). Attention-demanding tasks induce decreased local activations in this network as the "default mode" is temporally suspended. These areas include the anterior and posterior cingulate cortex. As shown in Fig. 8, affirmative shows more cingulate activation than negative; that is, negative induces a relative 'decrease' in default mode activation. Hence, the linguistic, psycholinguistic, and neurolinguistic data converge and suggest a default role for affirmative.

\section{Conclusions}

Negative sentences have a dedicated structure for the negative operator, a part of the clausal structure which is unique to negation; i.e., negative sentences have more syntactic structure than affirmative sentences. This additional structure requires additional syntactic computation. Indeed, contrasting negative and affirmative sentences reveal increased activation in the left premotor cortex, BA 6, an area involved in rule-based, non-motor cognitive manipulation of representations in working memory. There was no effect of syntactic structure in Broca's area which is typically associated with certain types of syntactic computation.

Affirmative sentences are upward entailing, whereas negative ones are downward entailing. Arguably, then, affirmative sentences involve more, general high-level semantic structure than negative ones. The affirmative $>$ negative contrast revealed increased activation in the right supramarginal gyrus, BA 40, and area involved in lexical retrieval and high-level hierarchical multimodal association.

Finally, syntactic analysis, behavioural data, and neuroimaging data converge on the conclusion that affirmative is default.

\section{Acknowledgements}

The work reported here was supported by a grant from the Danish National Research Foundation to the Center for Functionally Integrative Neuroscience (CFIN), by grant \#273-06-0248 from the Danish Research Council for the Humanities (under the Ministry of Science, Technology and Innovation), and by a grant from Linguistic Graduate School North, University of Aarhus. Thanks to Frank Thomsen for developing the presentation software. 


\section{Appendix. Stimulus material}

Target Pro

De smarteste folk møder og kender også bagere

The smartest people meet and know also bakers

"The smartest people meet and know bakers too."

De kedeligste kvinder elsker og drikker også kaffe

The most boring women love and drink also coffee

"The most boring women love and drink coffee too."

De klogeste folk elsker og savner også selskab

The cleverest people love and miss also company

"The cleverest people love and miss company too."

De dummeste mænd kender og læser også bøger

The stupidest men know and read also books

"The stupidest men know and read books too."

De sjoveste piger kender og drikker også vand

The funniest girls know and drink also water

"The funniest girls know and drink water too."

De ledeste kvinder sårer og snyder også folk

The meanest women hurt and cheat also people

"The meanest women hurt and cheat people too."

De ondeste mænd kender og køber også kunst

The cruelest men know and buy also art

"The cruelest men know and buy art too."

De dygtigste mænd ansætter og betaler også folk

The most talented men employ and pay also people

"The most talented men employ and pay people too."

De grimmeste kvinder kender og bruger også sminke

The ugliest women know and use also make-up

"The ugliest women know and use make-up too."

De flotteste kvinder kender og spiser også kager

The prettiest women know and eat also cakes

"The prettiest women know and eat cake too."

De sejeste mænd kender og bruger også sæbe

The toughest men know and use also soap

"The toughest men know and use soap too."

De særeste kvinder møder og elsker også børn

The strangest women meet and love also children

"The strangest women meet and love children too."

De sygeste mænd kontakter og møder også læger

The sickest men contact and meet also doctors

"The sickest men contact and meet doctors too."

De mærkeligste mænd kender og bruger også sminke

The strangest men know and use also make-up

"The strangest men know and use make-up too."
Visse smarte folk møder ikke bagere

Certain smart people meet not bakers

"Certain smart people do not meet bakers."

Visse kedelige personer drikker ikke kaffe

Certain boring persons drink not coffee

"Certain boring persons do not drink coffee."

Visse kloge folk elsker ikke selskab

Certain clever people love not company

"Certain clever people do not love company."

Visse dumme personer læser ikke bøger

Certain stupid persons read not books

"Certain stupid persons do not read books."

De sjoveste piger drikker ikke vand

The funniest girls drink not water

"The funniest girls do not drink water."

Visse lede personer snyder ikke folk

Certain mean persons cheat not people

"Certain mean persons do not cheat people."

De ondeste mænd køber ikke kunst

The cruelest men buy not art

"The cruelest men do not buy art."

Visse dygtige personer ansætter også folk

Certain talented persons employ also people

"Certain talented persons employ people too."

De grimmeste kvinder kender også sminke

The ugliest women know also make-up

"The ugliest women know (about) make-up too."

Visse flotte personer kender også kager

Certain pretty persons know also cakes

"Certain pretty persons know cake too."

De sejeste mænd kender også sæbe

The toughest men know also soap

"The toughest men know (about) soap too."

Visse sære personer elsker også børn

Certain strange persons love also children

"Certain strange persons love children too."

Visse syge personer kontakter også læger

Certain sick persons contact also doctors

"Certain sick persons contact doctors too."

Visse mærkelige personer bruger også sminke

Certain strange persons use also make-up

"Certain strange persons use make-up too." 
Appendix (continued)

Target Prob

De smarteste folk møder men kender ikke bagere

The smartest people meet but know not bakers

"The smartest people meet but do not know bakers."

De kedeligste kvinder elsker men drikker ikke kaffe The most boring women love but drink not coffee "The most boring women love but do not drink coffee."

De klogeste folk elsker men savner ikke selskab

The cleverest people love but miss not company

"The cleverest people love but do not miss company."

De dummeste mænd kender men læser ikke bøger

The stupidest men know but read not books

"The stupidest men know but do not read books."

De sjoveste piger kender men drikker ikke vand

The funniest girls know but drink not water

"The funniest girls know but do not drink water."

De ledeste kvinder sårer men snyder ikke folk

The meanest women hurt but cheat not people

"The meanest women hurt but do not cheat people."

De ondeste mænd kender men køber ikke kunst

The cruelest men know but buy not art

"The cruelest men know but do not buy art."

De dygtigste mænd ansætter men betaler ikke folk

The most talented men employ but pay not people

"The most talented men employ but do not pay people."

De grimmeste kvinder kender men bruger ikke sminke

The ugliest women know but use not make-up

"The ugliest women know but do not use make-up."

De flotteste kvinder kender men spiser ikke kager

The prettiest women know but eat not cakes

"The prettiest women know but do not eat cake."

De sejeste mænd kender men bruger ikke sæbe

The toughest men know but use not soap

"The toughest men know but do not use soap."

De særeste kvinder møder men elsker ikke børn

The strangest women meet but love not children

"The strangest women meet but do not love children."

De sygeste mænd kontakter men møder ikke læger

The sickest men contact but meet not doctors

"The sickest men contact but do not meet doctors."

De mærkeligste mænd kender men bruger ikke sminke

The strangest men know but use not make-up

"The strangest men know but do not use make-up."
Visse smarte folk møder ikke bagere

Certain smart people meet not bakers

"Certain smart people do not meet bakers."

Visse kedelige personer elsker ikke kaffe

Certain boring persons love not coffee

"Certain boring persons do not love coffee."

Visse kloge folk elsker ikke selskab

Certain clever people love not company

"Certain clever people do not love company."

Visse dumme personer kender ikke bøger

Certain stupid persons know not books

"Certain stupid persons do not know (about) books."

De sjoveste piger kender ikke vand

The funniest girls know not water

"The funniest girls do not know (about) water."

Visse lede personer sårer ikke folk

Certain mean persons hurt not people

"Certain mean persons do not hurt people."

De ondeste mænd kender ikke kunst

The cruelest men know not art

"The cruelest men do not know (about) art."

De dygtigste mænd ansætter også folk

The most talented men employ also people

"The most talented men employ people too."

De grimmeste kvinder kender også sminke

The ugliest women know also make-up

"The ugliest women know (about) make-up too."

Visse flotte personer kender også kager

Certain pretty persons know also cakes

"Certain pretty persons know (about) cake too."

De sejeste mænd kender også sæbe

The toughest men know also soap

"The toughest men know (about) soap too."

Visse sære personer møder også børn

Certain strange persons meet also children

"Certain strange persons meet children too."

De syge personer kontakter også læger

The sick persons contact also doctors

"The sick persons contact doctors too."

Visse mærkelige personer bruger også sminke

Certain strange persons use also make-up

"Certain strange persons use make-up too." 


\section{References}

Ben-Shachar, M., Hendler, T., Kahn, I., Ben-Bashat, D., \& Grodzinsky, Y. (2003). The neural reality of syntactic transformations: evidence from fMRI. Psychological Science, 14.5, 433-440.

Ben-Shachar, M., Palti, D., \& Grodzinsky, Y. (2004). Neural correlates of syntactic movement: converging evidence from two fMRI experiments. NeuroImage, 21, 1320-1336.

Bor, D., Cumming, N., Scott, C. E. L., \& Owen, M. (2004). Prefrontal cortical involvement in verbal encoding strategies. European Journal of Neuroscience, 19.12, 3365-3370.

Bor, D., \& Owen, M. (2007). A common prefrontal-parietal network for mnemonic and mathematical recoding strategies within working memory. Cerebral Cortex, 17, 778-786.

Bornkessel, I., Zysset, S., Friederici, A. D., von Cramon, D. Y., \& Schlesewsky, M. (2005). Who did what to whom? The neural basis of argument hierarchies during language comprehension. NeuroImage, 26, 221-233.

Carpenter, P. A., \& Just, M. A. (1975). Sentence comprehension: a psycholinguistic processing model of verification. Psychological Review, 82, 45-73.

Carpenter, P. A., Just, M. A., Keller, T. A., Eddy, W. F., \& Thulborn, K. R. (1999). Time course of fMRI-activation in language and spatial networks during sentence comprehension. NeuroImage, 10, 216-224.

Chase, W. G., \& Clark, H. H. (1972). Mental operations in the comparison of sentences and pictures. In L. Gregg (Ed.), Cognition in learning and memory. New York: Wiley.

Christensen, K. R. (2005). Interfaces: Negation - Syntax - Brain. PhD dissertation, Department of English, University of Aarhus.

Christensen, K. R. (2008). Interfaces, syntactic movement, and neural activation: a new perspective on the implementation of language in the brain. Journal of Neurolinguistics, 21.2, 73-103.

Christensen, K. R., Roepstorff, A., Saddy, D., Stødkilde-Jørgensen, H., \& Vikner, S. Negated implausibility and Broca’s area, submitted for publication.

Damasio, H., Grabowsky, T. J., Tranel, D., Ponto, L. L. B., Hichwa, R. D., \& Damasio, A. (2001). Neural correlates of naming actions and of naming spatial relations. NeuroImage, 13.4, 1053-1064.

Dogil, G., Ackermann, H., Grodd, W., Haider, H., Kamp, H., Mayer, J., et al. (2002). The speaking brain: a tutorial introduction to fMRI experiments in the production of speech, prosody and syntax. Journal of Neurolinguistics, 15, 59-90.

Farrer, C., \& Frith, C. D. (2002). Experiencing oneself vs another person as being the cause of an action: the neural correlates of the experience of agency. NeuroImage, 15, 596-603.

Franson, P. (2006). How default is the default mode of brain function? Further evidence from intrinsic BOLD signal fluctuations. Neuropsychologia, 44, 2836-2845.

Fuster, J. M. (2003). Cortex and mind. Unifying cognition. Oxford: Oxford University Press.

Grézes, J., \& Decety, J. (2001). Functional anatomy of execution, mental simulation, observation, and verb generation of actions: a meta-analysis. Human Brain Mapping, 12, 1-19.

Grodzinsky, Y. (2000). The neurology of syntax: language use without Broca's area. Behavioral and Brain Sciences, 23.1, 1-71.

Haegeman, L. (1995). The syntax of negation. Cambridge: Cambridge University Press.

Hanakawa, T., Honda, M., Sawamoto, N., Okada, T., Yonekura, Y., Fukuyama, H., et al. (2002). The role of rostral Brodmann area 6 in mental-operation tasks: an integrative neuroimaging approach. Cerebral Cortex, 12, 11571170 .

Hasegawa, M., Carpenter, P. A., \& Just, M. A. (2002). An fMRI study of bilingual sentence comprehension and workload. NeuroImage, 15, 647-660.

Hasson, U., \& Glucksberg, S. (2006). Does understanding negation entail affirmation? An examination of negated metaphors. Journal of Pragmatics, 38.7, 1015-1032.

Hockett, C. (1966). The problem of universals in language. In J. H. Greenberg (Ed.), Universals of language (2nd ed.). (pp. 1-29) Cambridge, MA: MIT Press.

Horn, L. (2001). A natural history of negation. Stanford: CSLI Publications.

Jordan, P. J. (1998). The power of negation in English: text, context and relevance. Journal of Pragmatics, $29,705-752$.

Joseph, R. (1996). Neuropsychiatry, neuropsychology, clinical neuroscience. New York: Academic Press.

Jung-Beeman, M. (2005). Bilateral brain processes for comprehending natural language. Trends in Cognitive Science, $9.11,512-518$.

Kaup, B., Lüdtke, J., \& Zwaan, R. A. (2006). Processing negated sentences with contradictory predicates: is a door that is not open mentally closed? Journal of Pragmatics, 38, 1033-1050. 
Kaup, B., Lüdtke, J., \& Zwaan, R. A. (2007). The experiential view of language comprehension: how is negated text information represented? In F. Schmalhofer, \& C. A. Perfetti (Eds.), Higher level language processes in the brain: Inference and comprehension processes. Mahwah, NJ: Erlbaum.

Mayo, R., Schul, Y., \& Burnstein, E. (2004). "I am not guilty" vs "I am innocent": successful negation may depend on the schema used for its encoding. Journal of Experimental Social Psychology, 40, 433-449.

Mesulam, M.-M. (1998). From sensation to cognition. Brain, 121, 1013-1052.

Mesulam, M.-M. (2002). Brain anatomy and networks. In V. S. Ramachandran (Ed.), Encyclopedia of the human brain (pp. 469-480). San Diego: Academic Press.

Moro, A., Tettamanti, M., Perani, D., Donati, C., Cappa, S. F., \& Fazio, F. (2001). Syntax and the brain: disentangling grammar by selective anomalies. NeuroImage, 13, 110-118.

Pinker, S. (1999). Words and rules: The ingredients of language. New York: HarperCollins.

Pollock, J.-Y. (1989). Verb movement, universal grammar, and the structure of IP. Linguistic Inquiry, $20.3,365-424$.

Raichle, M. E., MacLeod, A. M., Snyder, A. Z., Powers, W. J., Gusnard, D. A., \& Shulman, G. L. (2001). A default mode of brain function. PNAS, 98.2, 676-682.

Röder, B., Stock, O., Neville, H., Bien, S., \& Rösler, F. (2002). Brain activation modulated by the comprehension of normal and pseudo-word sentences of different processing demands: a functional magnetic resonance imaging study. Neurolmage, 15, 1003-1014.

Ross, J. R. (1984). Inner islands. In Proceedings of BLS 10 (pp. 258-265). Berkeley, CA: Berkeley Linguistics Society.

Russ, M. O., Mack, W., Grama, C. R. G., Lanfermann, H., \& Knopf, M. (2003). Enactment effect in memory: evidence concerning the function of the supramarginal gyrus. Experimental Brain Research, 149, 497-504.

Saddy, D., Drenhaus, H., \& Frisch, S. (2004). Processing polarity items: contrastive licensing costs. Brain and Language, 90, 495-502.

Smith, E. E., \& Jonides, J. (1999). Storage and executive processes in the frontal lobes. Science, 283, $1657-1661$.

Stromswold, K., Caplan, D., Alpert, N., \& Rauch, S. (1996). Localization of syntactic comprehension by positron emission tomography. Brain and Language, 52, 452-473.

Talairach, J., \& Tournoux, P. (1988). Co-planar stereotaxic atlas of the human brain. New York: Thieme Medical Publishers, Inc..

Tettamanti, M., Manenti, R., Della Rosa, P. A., Falini, A., Perani, D., Cappa, S. F., et al. The effects of sentential negation on action representation. Poster presented at the 12th annual meeting of the organization for human brain mapping (HBM 2006), June 14, 2006, Florence, Italy.

Vikner, S. (1995). Verb movement and expletive subjects in the Germanic languages. New York: Oxford University Press. 